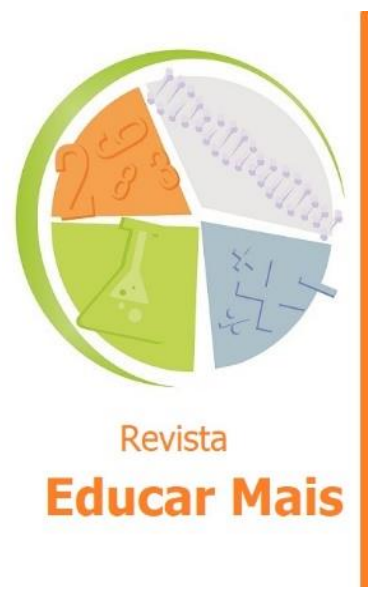

\title{
"A casa torta" e a formação pedagógica: deslizando os sentidos da infância
}

\author{
"Crooked house" and pedagogical education: sliding the senses of \\ childhood
} "La casa torcida" y la formación pedagógica: deslizar los sentidos de
la infancia

Mário Ferreira Resende ${ }^{1^{(D)}}$; Gleici Kelly de Lima ${ }^{(\mathbb{D})}$; Sara Nunes ${ }^{(\mathbb{D})}$

\section{RESUMO}

Este trabalho toma a obra "A Casa Torta" como ponto de injunção de três planos discursivos entorno da representação da infância. $1^{\circ}$, da autora, Agatha Christie, circunscrita pelas regras que regem o romance policial enquanto gênero literário. $2^{\circ}$, da narrativa, a criança Josephine, elevada ao estatuto de personagem conceitual, e, $3^{\circ}$, da experiência da leitura desse livro como possibilidade para o processo de formação em pedagogia. Propõe-se a articulação desses planos como forma de contraposição aos discursos homogeneizadores entorno da infância, como efeito de deslocamentos na produção dos sentidos. Apoiados pela Análise de Discurso Francesa, que assinala os limites das interpretações como o próprio lugar do trabalho do analista, destacamos a potência da representação da criança torta quando desconectada do erro ou do patológico, e atrelada à presença de um hiato que nos desafia a preencher com a precariedade da palavra. Nesse mesmo processo, a criança torta na educação é aquela que resiste tanto às rotinas escolares, quanto à aprendizagem, colocandose em posição deslocada e dando a ver o processo de produção de sentidos em suas formas históricas.

Palavras-chave: Personagem conceitual; Infância; Literatura; Formação de professores.

\begin{abstract}
This work takes the work "The Crooked House" as an injunction point of three discursive planes around the representation of childhood. First, of the author, Agatha Christie, circumscribed by the rules that govern the detective novel as a literary genre. Second, of the narrative, the child Josephine, elevated to the status of a conceptual character, and third, the experience of reading this book as a possibility for the process of training in pedagogy. We propose the articulation of these plans as a way of opposing the homogenizing discourses around childhood, as an effect of displacements in the production of meanings. Supported by the French Discourse Analysis, which points out the limits of the interpretations as the very place of the analyst's work, we highlight the power of the representation of the crooked child when disconnected from the error or the pathological, and linked to the presence of a gap that challenges us to fill with the precariousness of the word. In this same process, the crooked child in education is the one who resists both school routines and learning, placing himself in a displaced position and showing the process of sense production in its historical forms.
\end{abstract}

Keywords: Conceptual Character; Childhood; Literature; Teacher Training.

${ }^{1}$ Graduado, Mestre e Doutor em Psicologia e Professor do Instituto Federal Catarinense (IFC), Blumenau/SC Brasil. E-mail: mario.resende@ifc.edu.br

${ }^{2}$ Licenciada em Pedagogia, Mestra e Doutoranda em Educação para a Ciência na Universidade Estadual Paulista (UNESP), Bauru/SP - Brasil. E-mail: g.lima@unesp.br

3 Licenciatura e bacharel em história, Mestra e Doutora em História e Professora do Instituto Federal Catarinense (IFC), Blumenau/SC - Brasil. E-mail: sara.nunes@ifc.edu.br 


\section{RESUMEN}

Este trabajo toma la obra "La casa torcida" como punto de partida de tres planos discursivos en torno a la representación de la infancia. En primer lugar, la autora, Agatha Christie, circunscrita a las reglas que rigen la novela policíaca como género literario; en segundo lugar, la narración, la niña Josephine, elevada a la categoría de personaje conceptual, y en tercer lugar, la experiencia de la lectura de este libro como posibilidad para el proceso de formación en pedagogía. Se propone la articulación de estos planes como una forma de oposición a los discursos homogeneizadores en torno a la infancia, como efecto de los desplazamientos en la producción de sentidos. Apoyados en el Análisis del Discurso francés, que señala los límites de las interpretaciones como el lugar mismo del trabajo del analista, destacamos el poder de la representación del niño torcido cuando se desconecta del error o de lo patológico, y se vincula a la presencia de un vacío que nos desafía a llenar con la precariedad de la palabra. En este mismo proceso, el niño torcido en la educación es el que se resiste tanto a las rutinas escolares como al aprendizaje, colocándose en una posición desplazada y mostrando el proceso de producción de significados en sus formas históricas.

Palabras clave: Carácter conceptual; Infancia; Literatura; Formación del profesorado.

\section{DESLIZES INTRODUTÓRIOS}

Tomando como objeto de análise o romance policial "A casa torta", de Agatha Christie, esse trabalho propõe colocar no centro da discussão a injunção de três planos discursivos de composição que se conectam ao fazerem movimentar as representações entorno da infância. Em primeiro plano a autora, já reconhecida como a "Dama do Crime", escrevendo seu $53^{\circ}$ livro, um de seus preferidos, circunscrita pelas regras que regem o romance policial enquanto gênero literário. Em segundo plano, já na narrativa, a criança Josephine, aqui elevada ao estatuto de personagem conceitual, tal como postulado por Gilles Deleuze. E em terceiro plano, a inscrição da experiência da leitura desse livro como possibilidade para o processo de formação em pedagogia, arraigado entorno da primazia do infantil. O que queremos mostrar aqui é que esses três planos ao agirem entre si engendram possibilidades de escritas de resistência, operadas por deslocamentos em relação aos seus referenciais homogeneizadores, efeito de deslizamentos nos limites dos sentidos do infantil.

Assim como são as regras do romance policial que configuram o interdiscurso sobre o qual Agatha Christie se coloca em jogo através da escrita; são as regras entorno do discurso pedagógico que conformam a memória discursiva que desafia o lugar ético do pedagogo no jogo da sua formação e como estes veem as infâncias. Os dois planos de engendramento do discurso - o romance policial em "A casa torta" e a formação em educação - articulam o infantil pela experiência de formular um dizer sobre a criança a partir de traços que se associam a determinados efeitos de sentidos que fornecem à criança as suas (des)medidas, de modo que qualquer um possa dizê-la a partir dos liames históricos e sociais que a configuram. Nossa hipótese: a leitura desse romance em um contexto de formação pedagógica agencia uma posição de fruição com o texto ${ }^{1}$ que promove a conexão dos corpos associados aos três planos (escritora, personagem, leitor) articulados sobre deslocamentos do infantil cujo efeito é o de abrir representações impensadas para a infância, seja na literatura, seja naquilo que está em pauta no aprender e no ensinar. Desta maneira propomos um olhar outro às crianças, que possamos reconhecer as formações discursivas das crianças "tortas" e compreendê-las por meio do que nos demandam e não daquilo que somente queremos moralizá-las. Que a educação seja também um reconhecimento das margens diante dos pequenos que insistimos em nos cegar.

"O vovô não me deixou aprender a dançar balé, então decidi que ia matar ele. Aí vamos morar em Londres e mamãe não liga se eu fizer balé" (CHRISTIE, 2017, p. 211). Essas são as primeiras linhas 
do diário recuperado pela polícia, escrito por Josephine, que ali registrou a confissão de seu crime, antes do seu trágico final. E essa seria mais uma na série de personagens assassinos escritos por Agatha Christie se sobre ela não recaíssem dois pontos que Ihe conferem uma radical singularidade: primeiro, Josephine é uma criança e segundo, esse foi um dos romances preferidos da autora, que logo no prefácio confessa ser um dos dois que mais lhe deram prazer escrever. Entre a escrita da autora, no prefácio, assumindo o prazer de seu gesto; e a escrita da personagem em seu diário, assumindo seu crime, se interpõe o leitor-educador, cujo gesto agencia multiplicidades discursivas que colocam em jogo questões entorno da autoria e da infância.

\section{CAMINHOS METODOLÓGICOS}

Para Orlandi (2002) o lugar do trabalho do analista de discurso é nos limites das interpretações, colocando-se em posição deslocada para poder contemplar o processo de produção de sentidos em suas condições históricas. Assim, "[...] Ao olhar os textos, o analista se defronta com a necessidade de reconhecer, em sua materialidade discursiva, os indícios (vestígios, pistas) dos processos de significação aí inscritos [...]". (ORLANDI, 2002, p. 89-90) Buscando um movimento dos sentidos,

[...] errância dos sujeitos, lugares provisórios de conjunção e dispersão, de unidade e de diversidade, de indistinção, de incerteza de trajetos, de ancoragem e de vestígios: isto é discurso, isto é o ritual da palavra. [...] toda formação social, no entanto, tem formas de controle da interpretação, que são historicamente determinadas: há modos de se interpretar, não é todo mundo que pode interpretar de acordo com sua vontade, há especialistas [...]. Os sentidos estão sempre "administrados", não estão soltos. Diante de qualquer fato, de qualquer objeto simbólico somos instados a interpretar, havendo uma injunção a interpretar. Ao falar, interpretamos [...]. (ORLANDI, 2002, p. 10)

Assumir a análise do texto a partir de sua opacidade, ou seja, reconhecendo que nele não há qualquer evidência de sentido, corresponde à instalação de um conjunto de procedimentos colocados em execução na presença do texto afim de puxar e localizar os fios sobre os quais deslizam os discursos no limiar tênue que separa os sentidos e divide o dentro e o fora da obra, assim como o poder e o não poder significar.

Segundo Michel Foucault (2002), para analisar o discurso na opacidade do texto é preciso fazer aparecer nele o espaço intensivo em que se desenvolvem os acontecimentos sem a necessidade de remetê-los a qualquer isolamento que nada poderia superar, fechando-os em si mesmos. Quebrar a unidade do discurso, adverte Foucault, é justamente não postular uma verdade de sentido, mas atravessar o texto como algo permanentemente suspenso, aberto a outras possibilidades, algumas até imprevistas e imprevisíveis, e que podem guardar potências transgressoras de resistência. Com o texto em suspensão não apenas apontamos os sentidos e as trocas de sentidos na cadeia narrativa, mas assinalamos analiticamente as condições em que essas trocas podem acontecer, reconhecendo a polissemia do texto como uma pluralidade de trajetos. E é dessa forma que trazemos para a análise o romance policial "A Casa Torta", de Agatha Christie, lançado em 1949. Para a análise elaboramos a injunção de três planos discursivos de composição que se conectam ao fazerem movimentar as representações entorno da infância. 10, o da autora, Agatha Christie, na escrita de "A casa torta", circunscrita pelas regras que regem o romance policial enquanto gênero literário. $2^{\circ}$, da narrativa, a criança Josephine, elevada ao estatuto de personagem conceitual, e, 30, da experiência da leitura desse livro como possibilidade para o processo de formação em pedagogia. A hipótese é que a injunção desses três planos engendra possibilidades de escritas de resistência, operadas por 
deslocamentos em relação aos seus referenciais homogeneizadores, efeito de deslizamentos nos limites dos sentidos do infantil.

\section{A ESCRITA DA AUTORA E O ROMANCE POLICIAL}

Observemos agora o estatuto de "puro prazer" conferido pela autora no prefácio acerca da obra, que agora reproduzimos na íntegra, por se tratar de um valioso elemento de análise.

Este é um dos meus livros favoritos. Guardei a história por muitos anos, refletindo, elaborando, dizendo a mim mesma: 'um dia, quando tiver bastante tempo e quiser me divertir muito, vou começá-la'. Devo admitir que, dos livros produzidos por um autor, cinco são trabalhosos e um é prazer de verdade. A Casa Torta foi puro prazer. Muitas vezes me pergunto se os leitores conseguem identificar quando um livro foi o resultado de um trabalho árduo ou um deleite. Volta e meia alguém me diz: 'Você deve ter se divertido muito escrevendo tal livro!'. Isto em relação a uma obra que se recusava a sair do jeito que você queria, cujos personagens são difíceis, a trama desnecessariamente intricada e o diálogo artificial - ou pelo menos é assim que eu vejo. Mas talvez o autor não seja o melhor juiz da própria obra. No entanto, quase todo mundo gostou de A Casa Torta, o que corrobora minha crença de que se trata de um dos meus melhores livros. Não sei como a família Leonides me veio à cabeça - ela simplesmente veio. Então seus membros adquiriram vida própria e cresceram. Tenho a sensação de que lhes servi apenas de escriba. (CHRISTIE, 2017, p. s.p. Grifos nossos)

Mais do que uma declaração de predileção pela obra, trata-se de um testemunho do seu processo de escrita diante do inefável de personagens que ganham vidas e engendram dificuldades próprias, restando para o autor se sustentar na posição de suporte da escrita dessas trajetórias cujos destinos não são possíveis saber de antemão. Aqueles já familiarizados com o universo que cerca Agatha Christie sabe que ela gostava de comentar e escrever sobre suas obras. Existem diários, muitos ainda inéditos, cujos volumes disponibilizados nos permitem acompanhar seus procedimentos de escrita para os mais de 70 romances policiais que publicou. John Curran (2010) teve acesso a esses diários, que conferem nuances a cada um dos seus romances ao revelar dificuldades e deleites diferentes, rastros do seu exercício de criação. Pela observação dos diários, Curran pode constatar, por exemplo, que ela levou ao menos dois anos escrevendo "A Casa Torta", considerando que sua primeira menção ocorre no ano de 1947 e o romance só veio a ser lançado em Londres em 1949.

O segundo aspecto que confere especial interesse à obra está ligado ao seu desfecho: trata-se do único romance em que o assassino é uma criança, o que faz movimentar aspectos ligados às representações da infância e da criança no contexto histórico europeu da década de 40 . Esse inusitado desfecho foi na época tão chocante que resultou numa primeira intervenção direta da editora, solicitando a elaboração de um outro final alternativo, o que, sabemos, a autora recusou. (CURRAN, 2010, p. 138).

O romance policial, enquanto gênero literário, impõe algumas regras para a sua estrutura narrativa. A presença do crime é a mais evidente delas, mas não a única. Soma-se a deflagração do processo investigativo e, consequentemente, a revelação da identidade do assassino, mantida desconhecida até o desfecho. Outras características desse gênero literário emergem como efeitos dessas, como a presença do detetive, a quem cabe elucidar o mistério, além de características mais ideológicas, tal como a necessidade da punição do assassino, apresentado geralmente como estranho à ordem social, reificando a impossibilidade da existência do crime perfeito (REIMÃO, 1983). Agatha Christie é considerada uma mestra do gênero, atendendo a essas e outras das suas exigências, e o resultado 
é o sucesso de crítica e público do conjunto da sua obra. Mas a escrita de "A casa torta" estabelece um ponto de fuga aos ditames do gênero, bem como em relação aos seus romances anteriores, iluminando também um ponto singular de subjetivação da autora, de puro prazer.

São diversas as estratégias de escrita acionadas por Christie em seus romances cujos efeitos mascaram e tornam surpreendente a revelação final da identidade do assassino, que pode ser desde o narrador ou até mesmo o próprio policial que investiga o caso, mas nunca a autora havia até então experimentado a criança nessa posição. E, como revelam seus diários, será somente depois, em 1956, com o lançamento de "A extravagância do morto", que veremos a criança também ocupando a posição da vítima assassinada. E se em 1956 temos, com "A extravagância do morto ", a criança que termina assassinada em uma aparente brincadeira que dá errado a partir da intervenção de um adulto assassino é porque tivemos antes, em 1949, com "A casa torta", a posição ainda mais ousada da criança assassina. $O$ acesso aos diários nos permite estabelecer essa relação que coloca o infantil por duas vezes assumindo uma proporção assassina, seja como a criança que é morta, seja como a criança que executa o crime.

Destaca-se aqui o fragmento dos diários que corresponde ao momento em que a autora se vê no impasse do exercício da escrita desse último romance, reconhecendo, em meio as diferentes possibilidades disponíveis de vítimas, uma criança.

Quem irei matar? A aluna estrangeira? Não, ela não faz parte do plano... Alguém inesperado, então... que tal o lorde da casa? ... não, muito clichê... precisa haver impacto... que tal um estrangeiro?... mas quem... e isso traz um monte de problemas... deixarei isso para o ano que vem, talvez... Que tal uma criança? ... precisa ser tratado com cuidado, mas poderia ser uma criança não muito boazinha... Talvez o falso corpo, que poderia ser um dos escoteiros, aparece realmente morto, ... ou, melhor, uma escoteira... ela poderia ser muito intrometida e ter visto algo que não devia... não creio ter tido uma vítima que fosse criança antes. (CURRAN, 2010, p. 18-19, Grifos nossos)

Temos aqui, pelo gesto da escrita, o testemunho de uma autora em ato, se subjetivando no exato momento em que escreve, posicionada entre aquilo que ficará dentro, escrito no romance, e o que deixará de fora, tanto da obra, como de si, no campo da experimentação enquanto autora. E desse ponto podemos traçar um trajeto intensivo que une no corpo da autora essas duas obras que, em posições simétricas, conferiram o protagonismo da ação criminosa a uma criança.

\section{A CRIANÇA TORTA E A PERSONAGEM CONCEITUAL}

Com intuito de tratar a criança Josephine na imanência do plano em que aparece, ou seja, o universo ficcional, e rejeitar assim qualquer tentativa de enquadramentos patológicos ou mesmo psicológicos, propomos a aproximação ao que Gilles Deleuze (1992) denominou por personagem conceitual. Aludindo ao plano da filosofia e ao trabalho criativo do filósofo, o personagem conceitual aparece como o ponto singular onde o conceito em questão e o trabalho de criação se correspondem e passam a se remeter um para o outro. Aqui intervimos o ponto de aproximação que eleva a Josephine ao estatuto de personagem conceitual da escrita de Agatha Christie, uma vez que a personagem, encarnando expressões de mundos possíveis, opera ações na narrativa que movimenta todos os planos de composição, seja a inevitável realização do crime, seja a inscrição como puro prazer na memória da autora. 
A alusão ao universo simbólico do infantil não é raro no conjunto dos romances policiais escrito por Agatha Christie, de modo que cantigas de ninar, xaradas e outros jogos, frequentemente aparecem como fios condutores das narrativas, sendo também as chaves cruciais para a elucidação dos seus desfechos. E é na tessitura da escrita que a autora opera deslocamentos nesse campo simbólico, de modo a conseguir - a partir da justaposição do infantil com o medo, com o suspense - o efeito de fazer deslizar, por exemplo, uma rotineira brincadeira em algo macabro, de efeito mortal. Operando nesse sentido em "A casa torta", Agatha aciona o território simbólico das representações do infantil, numa articulação inventiva que conecta a narrativa do romance com a construção de uma criança capaz de matar, bem como de sua família, tomada como dispositivo que aciona e faz reverberar todo um conjunto de discursos históricos que circunscrevem o campo da infância.

Esta criança infernal, torta, representada pela personagem conceitual Josephine, criada por Agatha Christie cobra dos adultos, interrogando-os justamente no ponto em que fingem não a ver: "[...] A única coisa é que são burros! Não sabem onde olhar!" (CHRISTIE, 2017, p. 86)". Josephine ri dessa insistência adulta pela recusa a escutar e entender a criança, bem como de seus esforços por fazêlas distantes e invisíveis nas cenas em que estão. Elas nos chamam à escuta e o que fazemos é justamente ir à contrapelo deste pedido, dando-lhes tudo, menos a possibilidade de reverter a ordem natural das coisas. A doçura exagerada com que muitas vezes o adulto se dirige à criança é também o índice dessa distância e se põe à serviço de fazer da criança algo entre o invisível e o controlado por modelos idealizados. Como diz Benjamin, "[...]O gesto adocicado, que corresponde não à criança, mas às concepções distorcidas que se têm dela, sente-se a gosto nessas ilustrações. O formato perde a nobre discrição e torna-se incômodo". (BENJAMIN, 1984, p. 53). Passamos a adocicar os corpos por meio do brincar regrado, do ler moralizante e Christie (2017) nos chama novamente aos restos, para nos encontrar com o enfant perdido no meio das prisões da criança idealizada e morta.

Para escapar desse lugar das crianças, e sua história de invisibilidade ou de moralização, cabe-nos dialogar com Corazza (2002) que nos apresenta a criança infernal reconhecida no contexto educativo, que clama para ser escutada, mas principalmente pede para falar. Esses infernais que são também devires, como incita a autora, são linhas de fogo, às margens da história, "[...] sem passado nem futuro, ascendentes e descendentes, memória e filiação. São multiplicidades que não se deixam dicotomizar, rizomas que não se deixam arborizar, buracos negros que não se deixam aglomerar, muros brancos que não podem ser pichados". (CORAZZA, 2002, p. 51) São estas as crianças que não se deixam capturar que carregam a potência infernal de desafiar a educação para além da ortodoxia da didática e das metodologias.

E é assim que Josephine emerge na narrativa construída pelo gesto de escrita de Agatha Christie: uma criança torta, mas não apenas porque vai matar, mas por ser infernal de maneira a tencionar tanto os ditames do romance policial, quanto as representações entorno do infantil na educação. Essa criança infernal demanda a escuta dos adultos e pede que esses reconheçam suas produções, mesmo que tomadas como restos, à margem do que realmente interessa. Mas nessa sua exigência faz transparecer também justamente a potência que o adulto já perdeu: se recusar a assimilar sem resistência o estabelecido. (BENJAMIN, 1984) No agir de Josephine percebemos mais o corpo que pulsa na vontade de criar o mundo, do que o corpo submisso e pronto para mimetizar aquilo que the obrigam. E nesse pulsar, Josephine distorce proporções moralizantes consolidadas, nos dando a chance de se por à contrapelo do hegemônico ao inscrever a possibilidade de reverter a ordem natural das coisas, assinalando o princípio fundamental de toda filosofia para Deleuze (1992): o de que os universais não explicam nada, mas são eles próprios que devem ser explicados. 


\section{O QUE MATA A CRIANÇA QUE MATA? UM PERCURSO DE ANÁLISE DA OBRA "A CASA TORTA"}

Assumindo a compreensão de autoria desenvolvida por Michel Foucault (2001), os romances policiais escritos por Agatha Christie fazem parte daquele grupo de textos em que a função-autor é exercida não apenas numa amarração do sujeito à linguagem, mas como abertura de um espaço em que o sujeito é lançado e nele constitui um nome próprio: "Agatha Christie, a dama do crime". Aqui, importa quem escreve, pois, o texto não para de fazer relação com esse espaço circunscrito pelo nome próprio de sua escritora, e o faz de inúmeros modos, apontando para essa figura que lhe é simultaneamente anterior e exterior.

No caso dos romances policiais, a narrativa e a função de autoria se estabelecem em um curioso jogo com a morte, já que o crime, como vimos, é o maior dos imperativos desse gênero literário (REIMÃO, 1983). Na trama da narrativa do romance policial, o morto é sempre um grande protagonista, saturando a cena com traços do crime e dando corpo aos rastros que conduzirão ao criminoso. No gesto da escrita, assinala Foucault (2001), o singular de seu autor vem justamente pelo modo com que ele joga com a sua presença e a sua ausência na obra, e nos rastros e traços que ficam como resíduos dessa operação.

O nome do autor, como demarca Foucault (2001), não é um simples elemento, mas exerce importantes papéis em relação ao conjunto discursivo: assegura classificações, demarca oposições, reagrupa textos, exclui outros. Se deparar com um texto assinado pelo nome "Agatha Christie" significa ter nas mãos uma obra que, mesmo que se desconheça seu enredo específico, é possível de antemão inseri-la em redes anteriores de sentido do interdiscurso, permitindo, por exemplo, esperar dele o suspense e o exercício lógico de adivinhação e não um drama ou uma ficção científica. Nesse sentido, é significativo que os quatro romances não-policiais escritos pela autora foram assinados sob outro nome, o pseudônimo: "Mary Westmacott".

Ao traçar a arqueologia dessa função-autor, Foucault (2001) assinalou um importante ponto de conexão: é precisamente na relação com o campo do jurídico que se demarca a localização histórica dessa função quando, ao final do século XVIII, se instituiu todo um regime de propriedade para os textos, com regras editoriais e direitos de reprodução, entre outras coisas. Os textos, os livros, começaram a ter verdadeiramente autoria na medida em que a pessoa autor também passou a responder por aquilo que escrevia, podendo ser punida por isso, caso essa escrita alcançasse um perigoso lugar de transgressão.

Qualquer romance policial de Agatha Christie que tenhamos em mãos, aponta também para a presença dessa vida real da autora, colocada em jogo na escrita de livros que se sucedem, formando uma série espreitada pelo receio de não mais surpreender, de ver ser esgotada a sua fórmula de sucesso de público e de crítica. Não por acaso, conforme destaca Curran (2010), Agatha Christie não é apenas reconhecida pelo maior conjunto de romances policiais já escritos, mas sobretudo pela sua inventiva capacidade de operar variações sobre o mesmo tema, sem perder o efeito de surpreender. Forjava em seus diversos romances repetições de um mesmo recurso sem jamais esgotá-lo, mas atualizando a potência que transporta. O confinamento de personagens, por exemplo, é um desses recursos. Esse espaço, que assegura na narrativa a presença do assassino entre os suspeitos, pode ser um avião em movimento, um barco encalhado no meio do oceano, um trem parado na nevasca... não importa, trata-se de um estratagema para assegurar o desenrolar da trama num espaço restrito, 
mas que jamais se faz avesso à proliferação de suspeitas que passam a circular e recair sobre diferentes personagens até o momento da revelação final (CURRAN, 2010).

Para ser sujeito, nesse caso, sujeito de uma escrita, é inevitável também subjugar-se às redes de sentidos que precedem e que organizam os diversos discursos pelos quais a autora constrói suas personagens e seus planos de ação na narrativa. Seja com o campo da arqueologia e da cultura da antiguidade, presentes em romances famosos, como "Morte na Mesopotâmia"; ou com o universo dos compostos químicos e o sobrenatural, em "O cavalo amarelo", a autora precisa sempre arriscar escrever a partir de formações discursivas com as quais não tem, necessariamente, familiaridade.

Em "A casa torta" vemos Agatha Christie adentrando no território simbólico da infância, um universo absolutamente heterogêneo. A família Leonides, incluindo a pequena Josephine, está necessariamente atada a registros de classe social, raça, e a todo o contexto moral e de ideário familista que demarca a Inglaterra do pós-guerra e que dão suporte às representações de criança, contorno a seus lugares nos espaços sociais, bem como às suas possibilidades de se mover dentro deles. Mas ainda que o romance se cerque de signos que remetem ao universo simbólico que delimita a infância, ele criativamente opera deslocamentos em relação aos limites dessas ordens discursivas, conseguindo expor algo que não se articula com os sistemas dominantes de significação ao configurar o assassinato como um lugar possível para uma criança.

É assim que John Curran (2010, p. 138) resume o enredo e a narrativa do romance "A casa torta": "[...] Charles Hayward se apaixona por Sophia Leonides durante a guerra e fica fascinado pela família dela, que vive numa casa torta, comandada pelo avô rico. Quando ele é envenenado, é óbvio que um dos membros da família também é "torto", no sentido criminal." Logo terceiro capítulo, Agatha Christie (2017, p. 27) faz rebater sobre a casa que dá título ao romance, e que abriga a família, uma canção de ninar, vinda à memória do narrador no momento em que reflete sobre a estrutura arquitetonicamente torta da casa: "[...] Havia um homem torto e uma milha torta ele caminhou...Junto a uma escada torta uma moedinha torta encontrou...Um rato torto seu gato torto agarrou, E numa casinha torta esse grupo se aglomerou".

Funcionando já na zona do interdiscurso, a cantiga de ninar introduz na narrativa o campo simbólico que dá suporte ao romance: o infantil. Como já colocado, essa é uma estratégia presente em outros livros, como "Cem gramas de centeio" ou "O caso dos dez negrinhos", mas neles a cantiga infantil permitiu interpretar os crimes, entender sua motivação. Já em "A casa torta" temos um outro deslocamento, pois aqui a canção de ninar não apenas dá acesso ao entendimento do crime, que desafia a racionalidade, mas apresenta o campo de subjetivação próprio do criminoso: trata-se de uma criança que mata. Assim, a casa revela-se tortuosa não apenas por sua estrutura arquitetônica enviesada, mas por ser o teto que abriga a assombrosa coincidência do infantil com o crime.

Também em consonância com o título, Agatha Christie constrói uma narrativa tortuosa, não apenas para ludibriar o leitor e garantir a surpresa do desfecho, mas para articular a história de um assassinato que só pode ganhar realização a partir do agenciamento que dá passagem ao impossível ao sobrepor o crime ao agir da criança. Tomamos posse do mundo pelo brincar, mas Josephine fez do jogo algo real, deslizando a cena da imaginação para o ato concreto. E é justamente por conseguir manter a personagem o tempo todo no campo de subjetivação infantil que a Agatha Christie consegue assegurar o mistério do romance policial, fazendo dessa revelação final algo perturbador. 
Assim, Josephine, nosso personagem conceitual, não é construída pela autora como um adulto em miniatura assassino, mas se movimenta sempre como uma criança, que circula em meio a essa casa, tencionando as relações, expondo conflitos, contradições, hipocrisias. No meio das coisas, eis o lugar estratégico de Josephine, e que constitui todo o espaço da narrativa na escrita de Agatha Christie. Aliás, é esse lugar de mediação o que é mais próprio da criança, conforme afirma Deleuze (2011, p. 83): "A criança não para de dizer o que faz ou tenta fazer: explorar os meios, por trajetos dinâmicos, e traçar o mapa correspondente". Estar no meio é também se constituir numa posição dinâmica, assumida enquanto um exercício inconcluso que se assemelha ao traçar de um mapa, fazendo falar uma travessia, implicando as desventuras de um percurso e não a afirmação substantivada de quem busca um destino qualquer. $E$ do que é feito o meio, pergunta Deleuze? O meio é feito de uma grande heterogeneidade, que implica tanto diferentes qualidades e substâncias, quanto potências e acontecimentos. Trata-se de uma zona dinâmica, em perpétua potência de acontecimentos, de devires. (DELEUZE, 2011)

Esse é também o gesto de Josephine ao longo do romance: explorar os meios que dispõe, registrando tudo num caderninho que a acompanha, espécie de diário cartográfico que faz de seus deslocamentos algo visível, material. Seu percurso, sustentado pela escrita em seu diário, corresponde ao seu mapa, extensivo e intensivo, que no final trágico do romance torna-se o testemunho que encarna a confissão do crime que cometeu. Como vimos, uma vez encontrado, foi essa a sua primeira anotação: "Hoje matei meu avô".

Investida na e pela própria posição que circunscreve a infância, Josephine aí se movimenta, insinuando-se em meio aos que habitam a casa torta. A relação entre o pai assassinado e seu filho parecia ser harmônica? Está lá ela para dizer que não, pois ouviu, atrás da porta, uma séria discussão entre os dois, poucos dias antes do crime, incluindo o filho na lista cada vez mais extensa de suspeitos. Ouvir atrás das portas é, aliás, um dos procedimentos que a personagem coloca em prática algumas vezes ao longo do romance. Em um determinado ponto o narrador a interpela e questiona:

_ Josephine, ninguém nunca lhe disse que não se deve ficar ouvindo atrás das portas? Josephine fez que sim, movimentando a cabeça vigorosamente. É claro que me disseram isso. Mas se você quer descobrir as coisas, você tem que ouvir por trás das portas. Aposto que o inspetor chefe faz isso, você não? (CHRISTIE, 2017, p. 83)

Mais adiante, essa escuta intrusiva atrás das portas retorna ao fio da narrativa, mas agora, com o ápice da tensão na relação entre o narrador e a criança, que outra vez se vê confrontada a esse seu gesto, moralmente condenável, mas tão representativo do campo dos possíveis a uma criança, talvez um pouco travessa.

_ Você estava escutando por trás da porta mais uma vez?

_ Estava, eu gosto.

_ É uma coisa feia de se fazer, e lembre-se disso: quem escuta, de si ouve.

Josephine me olhou de um jeito esquisito.

Eu escutei o que ele falou de mim para ela, se é disso que você está falando. (CHRISTIE, 2017, p. 183)

São fragmentos que expõe esse movimento cartográfico da personagem que não se descola do universo do infantil, mas se afasta do pueril, o que a essa altura final do romance, põe em evidencia 
a grande cartada de Agatha Christie: a de nunca retirar a criança do infantil e movê-la em direção ao crime adulto, mas operar o inverso: trazer o crime para o infantil, na forma de uma criança que envenenou não apenas seu avô, mas também sua babá.

Escutar atrás das portas, mentir, aproveitar-se de seu tamanho diminuto para ver sem ser notada, são inúmeras as ações de Josephine que podem ser recolhidas no quadro que desenha um conjunto de comportamentos aceitáveis para uma criança. Até mesmo o envenenamento do avô, tem sua origem em uma conversa travada com a própria vítima, que ingenuamente forneceu o método para a sua pequena assassina, imiscuída entre todos os parentes, numa cena típica do universo de Agatha Christie, que coloca todos os suspeitos juntos e que fornece acesso à compreensão do crime.

_ Todos nós sabíamos. Um dia fomos todos para o quarto do vovô para tomar um café depois do almoço. Ele gostava de reunir a família inteira em volta dele, sabe? E seus olhos estavam doendo muito. A Brenda pegou a eserina para pingar uma gota em cada olho, e a Josephine, que sempre questiona tudo, falou: 'Por que está escrito 'colírio - não pode ser ingerido' no rótulo?' E o vovô sorriu e respondeu: 'Se Brenda se enganasse e injetasse o colírio em mim ao invés da insulina, imagino que eu respiraria fundo, minha cara ficaria azul, e depois eu morreria, porque meu coração não é muito forte'. E Josephine soltou um 'aah'e o vovô continuou: 'Então temos que tomar muito cuidado para que a Brenda não me dê uma injeção de eserina em vez de insulina, não é verdade?'. _ Sophia fez uma pausa e depois disse: _Nós todos ouvimos isso. Entendeu? Nós todos ouvimos (CHRISTIE, 2017, p. 118, Grifos nossos)

Situado pouco além da metade do livro, esse trecho funciona como um bom exemplo da estrutura genérica que configura os romances policiais, com pistas plantadas ao longo da narrativa, mas também como o procedimento que a autora põe em curso, a partir da singularidade de sua pequena assassina. Ela, a assassina, se expõe em êxtase - "aah" - por encontrar finalmente a via que conduz à realização de seus planos e desobstrui o acesso que permite ir ao encontro do seu objeto, as aulas de ballet em Londres. A assassina está lá, colocada sob a luz da narrativa, mas é apenas ao final do romance que entenderemos plenamente o significado dessa conversa testemunhada por todos da casa.

Nos romances policiais, entender um assassinato é entender também a motivação para a realização do crime (REIMÃO, 1983). E essa questão torna-se especialmente complexa nesse crime realizado na casa torta. Logo no início do romance essa questão é aludida pelo capitão Taverner, responsável pela investigação, ao contemplar o desafio de chegar ao assassino quando não se vê ainda a motivação para o crime. Aparentemente todos viviam bem, abrigados na casa torta, tendo seus presentes e futuros assegurados pelo patriarca Leonides. Como sintetiza o capitão: "Todo mundo nesta maldita casa teve meios e oportunidade. O que eu quero é a motivação" (CHRISTIE, 2017, p. 56).

Novamente ressaltamos o aspecto criativo da autora. Para se manter plenamente inscrita no domínio discursivo da infância é preciso que o motivo para o gesto seja ele mesmo também infantil, deslocando suas fronteiras de realização em direção ao impensável do crime. E ele o é, conforme vimos revelado pelo diário de Josephine, que confessou ter envenenado o avô por conta de sua oposição à mudança para Londres. A última anotação de seu caderninho também é reveladora:

Odeio a babá... odeio ela... odeio ela... Ela diz que eu não passo de uma garotinha. Ela diz que eu fico me exibindo. Ela está fazendo a minha mãe me mandar para o exterior... Vou matar ela também - acho que o remédio da tia Edith vai dar conta. Se acontecer outro assassinato, a polícia vai voltar e vai ser divertido outra vez. A babá morreu. Estou contente. Ainda não resolvi onde vou esconder o frasco com os 
comprimidos. Talvez no quarto da tia Clemency, ou do Eustace. Quando eu estiver velha e morrer, vou deixar isso endereçado ao chefe de polícia e eles vão ver que criminosa esperta eu fui. (CHRISTIE, 2017, p. 211)

Não apenas na motivação para o crime, encontramos no romance todo um conjunto de índices que apontam para o campo simbólico atribuído à performatização do infantil: o divertido, o escondeesconde, a imaginação, o exibicionismo tão peculiares da infância, os pensamentos mágicos..., porém todos eles operando à serviço de um movimento que, sem freios, desembocou no ato criminoso.

A revelação de Josephine vem acompanhada de um desfecho trágico. Sua tia enferma e desenganada, diante dessa revelação, sai com a criança de carro e o arrebenta na pedreira da estrada, matando ambas. Ocupando a posição impossível de assassina, Josephine foi levada à morte por sua tia, a mesma a quem confessou ao narrador ser a depositária do seu maior afeto. Antes de partir para a viagem suicida, a tia deixou um bilhete, destinado ao narrador, portador da "verdade", que precisava ser compartilhada.

Caro Charles. Esta carta é confidencial e dirigida apenas a você - e a Sophia, se assim desejar. É fundamental que alguém saiba a verdade. Achei o objeto em anexo no canil abandonado, junto à porta dos fundos. Ela o guardava lá. Confirma o que eu já suspeitava. A atitude que estou prestes a tomar pode ser certa ou errada - não sei. Mas a minha vida, de qualquer forma, já está chegando ao fim, e não quero que a menina sofra como acredito que sofreria se fosse obrigada a prestar contas à justiça terrena do que fez. Muitas vezes há um no meio de uma ninhada que 'não bate muito bem'. Se eu estiver enganada, que Deus me perdoe - mas fiz o que fiz por amor. Deus abençoe vocês dois. Edith de Haviland. (CHRISTIE, 2017, p. 210)

E assim chega-se ao trágico desfecho da criança torta da casa torta, criança que não parou de agenciar deslocamentos que a fizeram escapar do cerco dos adultos, verdadeira ameaça que lhe vinha de fora. É representativo que apenas a morte tenha podido ser confrontada com as mortes promovidas pelo agir criminoso de Josephine. Assegurada pelo agir adulto da sua tia preferida e desenganada, sua morte trouxe a essência da sua potência subversiva: Josephine ousou ser o que não se pode ser, trouxe uma impossibilidade ao campo da realização e, com isso, fez tremer a estrutura que dá subsistência ao campo simbólico que configura a infância. Expulsa desse lugar restaria a ela uma vida de constante sofrimento e humilhação, escreve a tia, também para acreditar no sentido verdadeiro do seu ato. Todos os adultos já puderam testemunhar o desejo de morte na fala de uma criança frente a alguma frustração, mas Josephine deslocou esse campo para o lugar instável da produção de uma criança que efetivamente matou, fazendo o crime passar de um estado de vontade cega para o da realização.

E recompondo o lugar ficcional dessa criança, coloquemos em primeiro plano o corpo da autora, com a pena na mão, agenciando uma escrita subversiva porque se faz movendo-se entre o dizível e o não-dizível que circunscreve o campo simbólico da infância. Talvez porque nela sua escrita se fez em devir-criança, cuja manifestação nos diários e no próprio prefácio do livro aparece como a grafia dessa letra, o resíduo desse gesto infantil de puro prazer e potência. É aqui que encontramos como resto desse gesto de escrita a predileção pela obra, e o prazer que ela envolve, reconhecido logo no prefácio. A autora está em plena consciência do que tem nas mãos e regozija-se nesse lugar que já é efeito da coragem de sua escrita.

Esse devir infantil apontado por Christie, de retomar os restos da infância potente, que deseja dialoga com o olhar à educação para além dos binarismos impostos à infância. Para Corazza (2002, p. 17), esse lugar da criança "torta", infernal, representada aqui neste devir da autora no personagem 
conceitual de Josephine, está longe dos dualismos e totalidades que a educação lhe impõe, 0 demoníaco passa a ser necessário na educação das crianças, "[...] na pastoral cristã do medo, na ordem mundial capitalista, nos divãs de edipianização, em todas as máquinas binárias de Estado. Exerceu uma função positiva na cultura do Ocidente, foi um importante fator constitutivo de novos governos, sociedade, racionalidade, tempo-espaço, organização do trabalho". Em tempos de morte é necessário pensar a história de um devir infantil que sempre nos delega a loucura, a morte e os restos infernais para além do angelical puritano:

Fora necessário que o humano entrasse no pensamento da finitude, mantendo-o implicado em sua temporalidade; referenciando-o à sua própria destruição; fazendo dele tanto a imagem de sua verdade quanto a eventualidade de sua morte; fixandoo na dialética da vida e da morte, por amar a Eros e temer a Tanatos: isso para que a criança ocidental pudesse aparecer como elemento deste devir - uma criança que, desse modo, parecia nascer da Morte e nesta encontrar sua matriz geral. (CORAZZA, 2004, p. 20-21)

Ao nos depararmos com as memórias da construção desta obra a partir da leitura de dos diários que escreveu, evidencia-se o jogo das representações entorno da infância em disputa na imaginação fértil da autora. No processo de escolha de qual personagem matar, a dificuldade de reconhecer a morte de crianças, bem como o quanto "romantizamos" os bibelôs infantis, investindo-os com pureza e divindade para além dos corpos que pulsam cotidianamente suas vontades. Esse contexto moral de uma Inglaterra do pós-guerra marca presença no jogo de escrita da autora, que faz a criança deslizar desse viés moralizador quando a consagra em sua escrita não apenas como a morta, mas também como a assassina.

O que Agatha Christie nos mostra é um poderoso deslocamento: ao invés do infantil que se aniquila no acontecimento dramático do crime, está a potência de subjetivação se fazendo no instante mesmo em que a infância tropeça e falha no corpo que dá forma à personagem Josephine e retorna como prazer na escrita da autora, invertendo o lugar historicamente atravessado que produz e reifica as representações das possibilidades de ser uma criança. Corpo textual e corpo da autora aparecem aí unidos na forma de um laço que faz transbordar a escrita do lugar de uma atividade técnica para uma prática corporal de gozo, conforme descreve Roland Barthes (2004, p.293).

\section{ASSOMBRO FINAL: ENTORTANDO A FORMAÇÃO PEDAGÓGICA}

Movimentando-se no conjunto histórico dos discursos que constituem o possível para uma criança na década de 40, o prazer da escrita de Agatha Christie se faz ressoar por toda a sua obra, materializada no vasto conjunto de livros que produziu e que lhe conferiu um nome no gênero literário dos romances policiais. Esse trabalho buscou colocar sua escrita no centro da experiência, tomada enquanto gesto arriscado de produção de si, forjando o elo material entre subjetivação e práticas de produção textual. Ambos, corpo e escrita, articulam-se num processo em que o gesto de escrever conecta o corpo textual ao corpo subjetivo daquela que o escreve: a dama do crime. Resta, no entanto, o terceiro plano de composição discursiva que estabeleceu o recorte desse artigo: a figura do leitor, quando tomado como um pedagogo em formação, fruindo pela leitura do texto de Agatha Christie, que sabe colocá-lo contra a parede ao levá-lo a reconhecer naquela pequena assassina, a criança. Como personagem conceitual que promove abalos nas representações estabelecidas para o infantil, Josephine também pode causar solavancos quando atravessa a formação em pedagogia, regida pela circulação hegemônica do discurso pedagógico. 
Reafirmando o discurso enquanto prática política, lugar de trabalho da língua e da ideologia, todo texto se constitui na tensão permanente entre o mesmo, a repetição, e o outro, a diferença. Ou entre a paráfrase e a polissemia, assinala Orlandi (1996), nomeando esses dois processos essenciais da articulação da linguagem. Assim, ao assumirmos a palavra podemos dizer mais do mesmo, ou, fazer do mesmo, outra coisa, implicá-lo na diferença, ainda que sob o risco de queda no non-sense, no não-sentido. E essa tensão que percorre todo o dizer se inscreve nos discursos que compõem nossos objetos, inclusive a criança, e a infância.

É justamente pensando nas maneiras com que os discursos vão se relacionar com os referentes e com os efeitos de sentido que produzem entre os interlocutores que Orlandi (1996) estabelece suas três formas, ou modos de funcionamento: o lúdico, o polêmico e o autoritário. Em termos dos processos de articulação da linguagem, podemos dizer que o discurso lúdico apresenta e estimula a polissemia, o discurso polêmico a permite sob certas condições e o discurso autoritário visa estancála por completo, estabelecendo o referencial único, o modelo. E para Orlandi, o discurso pedagógico é caracterizado de modo geral pelo autoritarismo e pela circularidade.

A escola é a sede do discurso pedagógico. Em última instância, é o fato de estar vinculado à escola, isto é, a uma instituição, que faz do discurso pedagógico aquilo que ele é, mostrando-o em sua função: um dizer institucionalizado, sobre as coisas, que se garante, garantindo a instituição em que se origina e para a qual tende. É esse o domínio de sua circularidade. Circularidade da qual vemos a possibilidade de rompimento através da crítica. (ORLANDI, 1996, p. 23)

Sendo definido pelo autoritarismo, já que historicamente opera pela proposição de formas ideais, que encontram correspondência em formações ideológicas que, em última instância, acabam por instituir modelos (de ensino, de aprendizagem, de aluno, de professores, de currículo etc.), qual é a saída crítica para o discurso pedagógico? Para Orlandi (1996), é a partir de uma virada em direção ao lúdico e ao polêmico que o discurso pedagógico pode romper com sua circularidade autoritária para apostar no jogo aberto da polissemia, único capaz de fazer irromper a diferença no seio da uniformidade.

A criança é por excelência o objeto para qual o discurso pedagógico se voltou, e a formação em Pedagogia coloca em evidência essa centralidade. A primazia entorno de questões entorno da infância permeia a Pedagogia tanto em sua forma mais clássica, preocupada com a ordem da qualidade desse saber a ser transmitido à criança, como também a partir do seu semblante moderno, atravessado pelas ciências, como a Psicologia, que a fez movimentar seu foco em direção à singularidade dos processos de aprender da criança, especialmente quando esses repousam em leis estruturais e modelos universais. É nessa dinâmica que a aproximação de Josephine pode cumprir a experiência que fornece a saída lúdica e polêmica para o enquadramento pedagógico entorno da criança, rompendo o controle da polissemia do conceito em favor de deixar aparecer outras possibilidades para além das hegemônicas.

Considerando a linguagem como o lugar do acontecimento, Josephine suscita um jogo polissêmico que aproxima o impensável impossível crime para o possível da linguagem, instituindo uma zona intensiva que extrapola o texto ao mesmo tempo que assinala o lugar da transgressão na linguagem. Um lugar que não tem a ver com aceitar ou rejeitar num quadro moral, mas no deixar ser como acontecimento, numa potente mudança de relação entre as coisas.

Os desdobramentos polissêmicos de Josephine são muitos, tantos quanto ousarmos inventar. Como metáfora possível, a criança torta e infernal da educação pode ser aquela que resiste tanto às rotinas 
escolares, quanto à aprendizagem e, tal como descreve Benjamin, está lá, sempre disposta a estranhar aquilo que para o adulto já parece familiar. O torto não corresponde a uma coisa errada, mas a presença de um hiato, um abismo, que nos desafia a preencher com a precariedade da palavra a busca pelos sentidos.

Buscando uma conclusão, trazemos aqui um texto no qual o historiador Michel de Certeau (2012), discorre sobre o riso de Michel Foucault, atribuindo seu lugar estratégico naquilo que entende ser 0 projeto político do amigo. Para Certeau, o riso do filósofo se convertia em verdadeira prática intelectual que transbordava o impensável dos acontecimentos, abrindo outras possibilidades que expunham o pensamento do filósofo ao outro lado do discurso, lado que corresponde ao posicionamento político pela resistência. O riso, a surpresa, o espanto, são também a percepção inicial da complexidade de um problema e de seu objeto, cujo assombro já pedia ao filósofo o gesto de criar maneiras mais inventivas e clandestinas de pensar.

O riso também remete ao infantil, mas como devir-criança, tradução do desejo de expandir-se, aventurar-se e formar novas combinações que, deslizando em seus próprios limites, expõe a infância como experiência de abertura à linguagem e à história, com toda a potência que isso significa. Assim, terminemos com o prazer, também infantil, da autora, arriscando-se numa escrita que dá visibilidade a outro espaço de operação do poder, cujos efeitos cumprem as exigências impostas pelo gênero literário, mas simultaneamente surpreendem essas mesmas estruturas. É Josephine, seu personagem conceitual, quem expõe a essência do seu trabalho de escritora: "A única coisa é que são burros! Não sabem onde olhar." São esses deslocamentos do olhar, que podem ser inscritos tanto na literatura quanto nas práticas educativas, que esse trabalho buscou atentar, assim como o prazer soberano de arriscar fazer e pensar diferente.

NOTA: Para Roland Barthes (1999), o texto de fruição desconforta o leitor ao desalojá-lo das formas fáceis, inaugurando uma experiência de crise e limite com a linguagem; já o texto de prazer, ao contrário, funda uma prática confortável de leitura, com escassas possibilidades de tensionamento dos referenciais organizadores da cultura.

\section{REFERÊNCIAS}

BARTHES, Roland. O prazer do texto. São Paulo: Editora Perspectiva, 1999.

BARTHES, Roland. Inéditos I: teoria. São Paulo: Martins Fontes, 2004.

BENJAMIN, Walter. Reflexões: a criança o brinquedo a educação. Trad. Marcus Vinicius Mazzari. $5^{a}$ ed. São Paulo: Summus, 1984.

CHRISTIE, Agatha. A casa torta. Porto Alegre: L\&PM, 2017.

CORAZZA, Sandra Mara. Para uma filosofia do inferno na educação: Nietzsche, Deleuze e outros malditos afins. Belo Horizonte: Autêntica, 2002.

CORAZZA, Sandra Mara. História da infância sem fim. 2. Ed. Ijuí: Ed. Unijuí, 2004.

CURRAN, John. Os diários secretos de Agatha Christie: $\mathbf{5 0}$ anos de mistério na criação. São Paulo: Leya, 2010. 
DE CERTEAU, Michel. O riso de Michel Foucaul. In: DE CERTEAU, Michel. História e Psicanálise: entre a ciência e a ficção. Belo Horizonte: Autêntica, 2012.

DELEUZE, Gilles. O que é a filosofia? Rio de Janeiro, Editora 34, 1992.

DELEUZE, Gilles. O que as crianças dizem. In: DELEUZE, Gilles. Crítica e clínica. São Paulo: Editora 34, 2011.

FOUCAULT, Michel. O que é um autor? Em: MOTTA, Manoel Barros da (org.) Michel Foucault: Ditos \& Escritos, Vol III. Estética: literatura e pintura, música e cinema. Rio de Janeiro: Forense Universitária, 2001.

FOUCAULT, Michel. A arqueologia do saber. 6.ed. Rio de Janeiro: Forense Universitária, 2002.

ORLANDI, Eni Puccinelli. O Discurso Pedagógico: a circularidade. In: ORLANDI, Eni Puccinelli. A linguagem e seu funcionamento: as formas do discurso. 4ed. Campinas: Pontes, 1996.

ORLANDI, Eni Puccinelli. Análise de discurso - princípios e procedimentos. 40ed. São Paulo: Pontes, 2002.

REIMÃO, Sandra Lúcia. O que é romance policial. São Paulo: brasiliense, 1983.

Submissão: 04/01/2022

Aceito: 13/01/2022 